\title{
'Woke Up This Morning:' How we got the (rhythm and) blues - and found some soul
}

Got my mojo working, but it just won't work on you Got my mojo working, but it just won't work on you I wanna love you so bad till I don't know what to do I'm going down to Louisiana to get me a mojo hand I'm going down to Louisiana to get me a mojo hand I'm gonna have all you women right here at my command

Muddy Waters, 'Got My Mojo Working'

AS THE FEARS aroused by jazz in the inter-war years bear witness, popular music in Britain was considered in terms of 'whiteness' and discussed in terms of the threats posed by alien, uncivilized forms of music and dancing. 'Black' or 'negro' music was seen as essentially 'other,' something that 'had an impact on,' rather than 'being part of' indigenous popular music, despite the longstanding presence of black communities and black musicians in Britain. Black-face minstrelsy in the nineteenth century, even more so, The Black and White Minstrel Show in the twentieth century, reinforced this sense of 'otherness.' The fact that 'negro minstrelsy' owed much to popular music brought from Britain and Ireland and, in turn, offered its own 'Irish' and 'Scotch' shows, did nothing to undermine this simplistic, racialised division between 'black' and 'white' music. The growing awareness of American popular music, from ragtime onwards, further reinforced this view, not least because American popular music had been re-constructed along racial 
lines from the late nineteenth century onwards. Part of the purpose of this and the next chapter is to demonstrate how the once 'other' became a central part of popular music in the latter part of the twentieth century.

Although widely used, terms such as 'the blues' and 'rhythm and blues', are elusive, giving rise to often bitter, but ultimately sterile, debates about what constituted authenticity and what was a bastardised or commercialised form of the music. Given its diverse roots in African rhythms and songs, work songs and field hollers as well as European balladry and hokum; given the blurred edges with boogie-woogie and ragtime; and given important regional variations, notably between the Mississippi Delta and Texas, it is more appropriate to use blues (and by extension, rhythm and blues) as a convenient umbrella term, rather than a precise definition. Similarly, given the commercial awareness of the earliest known/recorded bluesmen and blueswomen, it makes little sense to seek out and prioritise 'pure' or 'authentic' blues in terms of freedom from the corrupting influence of commercialization. Finally, the desire to find and preserve the 'true' blues (or any other music form) makes a nonsense of the ways in which popular music develops as circumstances (social and economic but also technological) change. Thus, a further purpose of this chapter is to move beyond such arguments and to focus on 'syncretic moments' and to argue for a developmental process of imitation, experimentation and fusion out of which new musical genres evolved.

\section{Discovering the blues in post-war Britain}

Awareness of the blues in Britain before, and even during, World War II was limited to a small number of aficionados. The situation changed after the war in no small measure as a result of the trad jazz revival, skiffle and the second folk revival. The interest in traditional jazz, and the desire of men such as Ken Colyer to recreate an 'authentic' New Orleans sound, led to a growing interest in its black roots. Blues were of interest because they were seen as 'the simplest form of jazz.' were record recitals of 'race' music and even formal lectures by such men as Paul Oliver, but the blues were very much a niche interest. The emergence of skiffle further increased awareness 
and interest. However flawed Lonnie Donegan's introduction to 'Rock Island Line' might have been, it brought Lead Belly's name to a wider audience than ever before. ${ }^{2}$ Albeit approaching from a different direction, the second folk revival also played its part, most notably through the work of the Ballad and Blues Association and of Alan Lomax in London, which culminated in Ballads and Blues, produced for the BBC in 1953, with its aim of providing 'folk singers and jazz musicians ... a common platform in modern and traditional folk music from both sides of the Atlantic.' Thus, Big Bill Broonzy was heard along with Ewan MacColl and A L Lloyd but also Humphrey Lyttleton, Seamus Ennis and Cy Grant.

The broadening of awareness of the blues was a slow process. Immediately after the war, there were only a small number of records from America, many brought in informally. ${ }^{3}$ There were a few minor record labels in Britain and the specialist record shops in London (Dobell's) and the larger cities (Hessy's in Liverpool and Collet's in Manchester) but they were not readily accessible for the majority of the population. ${ }^{4}$ The BBC very occasionally aired a programme which included blues music, such as Lomax's three-part series, The Art of the Negro, but, as with its policy towards jazz, this was confined to the Third Programme. ${ }^{5}$ Finally, the opportunities to see live musicians was restricted by the understandable but restrictive stance of the Musicians' Union, which was not relaxed until 1957. Nonetheless, a growing number of bluesmen toured Britain. Josh White and Lonnie Johnson in were among the first, but among the most influential were Big Bill Broonzy, John Lee Hooker, Memphis Slim, and 'Champion' Jack Dupree. ${ }^{6}$ Sonny Terry and Brownie McGhee, who appealed to part of the burgeoning folk club scene, also became regular visitors. For would-be British blues bands, tours gave some of them an opportunity to work with and learn from established American stars. The relationship was often difficult, not least because of the limited knowledge and ability of novice bands, but working with someone even as critical as Sonny Boy Williamson, "taught ... a lot about feel and emotion, and also ... improvisation." ${ }^{7}$ Growing interest, as much on continental Europe as in Britain, led to the annual American Folk Blues Festival, which brought an array of touring African-American 
blues musicians to several British venues, between 1962 and 1972. ${ }^{8}$ More importantly, Granada television decided to broadcast a 45-minute recording of the 1963 show - I Hear the Blues - which was followed up by a second programme, The Blues and Gospel Train in 1964.

These tours were important in raising awareness of the blues among British audiences, but it was a particular version of the blues that was anachronistic, inconsistent and heavily gendered. Sister Rosetta Tharpe was an undoubted star of The Blues and Gospel Train but the only woman in the cast list. Similarly, I Hear the Blues had only one female performer - Victoria Spivey. ${ }^{9}$ The blues were constructed in terms of the anguished male, in and of a rural environment and uncontaminated by any taint of commercialism. Lead Belly, Big Bill Broonzy and Muddy Waters could all be presented as - and more importantly were happy to play the part of - this archetypal blues singer. ${ }^{10}$ Consequently, women were marginalised, their often humorous and downright lewd songs expunged from the canon, and their popularity and commercial success denied. At the same time, the southern plantation image was totally at odds with the lived experience (and musical preferences) of 1960s African-Americans. The suffering, noble savage was an image that fitted well with a nation that prided itself on its role in abolishing the slave trade, without coming to terms with its contribution to the Atlantic slave trade and the extent to which British prosperity was rooted in slavery. Although more attention was paid to 'authenticity' than ever was the case with Victorian minstrelsy, the construction of the bluesman was effectively another re-working of older tropes, though ones in which participants were happy to connive. ${ }^{11}$ On a lighter note, it gave rise to incongruities such as the sight of Rosetta Tharpe's high-heels and Matt Murphy's electric guitar in an ante-bellum set for The Blues and Gospel Train. ${ }^{12}$

Murphy's anachronistic guitar leads to a final point about the music itself. In a debate about 'authenticity, on both sides of the Atlantic, purists emphasised the importance of the acoustic guitar. In so doing, they blinded themselves to changes that had taken place following the large-scale migration from the southern states to cities such as Chicago and set themselves up for disappointment when Lonnie Johnson sounded like an Ink 
Spots' tribute act and Muddy Waters played an electric guitar. British commentators, coming from jazz scholasticism and the preoccupation with authenticity, struggled, but eventually succeeded in accommodating Muddy Waters, B B King and John Lee Hooker in a tradition that included 'timeless artists [such] as Blind Willie Johnson, Barbecue Bob and Lewis Black' and their music, which went 'right back to West Africa in its primitive, almost chanting, ultra-rhythmic accompaniment.' ${ }^{13}$ There remained a grave suspicion of commercial exploitation. Rhythm and blues, the term increasingly used to describe the urban music of black mass migration, was still seen as 'a reprehensible bastardization of a fine folk form', in Albert McCarthy's words. ${ }^{14}$

The gradual growth of interest in rhythm and blues was a feature of late-1950s Britain. Broonzy, King and Waters gave it a degree of respectability as its popularity gradually grew. Skiffle and rock ' $n$ ' roll transformed attitudes and expanded audiences, bringing a new generation in touch with blues on a scale not previously experienced. Within a short space of time, men (and it was overwhelmingly men) who had listened in awe to the stars of The Blues and Gospel Train were themselves performing at the National Jazz and Blues Festivals alongside American artists. ${ }^{15}$

\section{The 1960s rhythm and blues boom and its aftermath}

London, 'the new Chicago,' according to Melody Maker, was the focus of much contemporary attention, but the rhythm and blues boom involved clubs and groups across the country. In London, the Eel Pie Island Hotel and the Crawdaddy Club (in Richmond) became well-known venues but more influential were the Marquee and the Flamingo. More importantly, rhythm and blues clubs were to be found not only in the major cities but also in smaller towns. By the end of 1963 estimates suggested some 2000 were in existence. The accompanying emergence of home-based rhythm and blues groups had an important impact on the evolution of popular music.

The first developments came from blues purists, notably Alexis Korner and Cyril Davies. They supported Muddy Waters on tour in 1958 and their London Blues and Barrelhouse Club became an important venue. Their band, 
Blues Incorporated, provided opportunities for a wide range of aspiring performers, and their 1962 album, $R \& B$ From the Marquee, was highly influential, though never a commercial success. The 12-track album was evenly divided between American numbers, including 'I've Got My Mojo Working'16 and 'Hoochie Coochie Man,' and compositions by band members. In 1962 Davies, more committed to Chicago-style blues, left, unhappy with the suggestion that their repertoire should be extended to include more popular Chuck Berry and Bo Diddley songs and their line-up augmented by horns. The short-lived Cyril Davies All Stars included Long John Baldry and Jimmy Page alongside members of Screaming Lord Sutch's Savages! Following Davies' death, the All Stars, led by Long John Baldry, were renamed as the Hoochie Coochie Men, and included in their number a young Rod Stewart and a keyboard player by the name of Reg Dwight.

If Blues Incorporated was a southern blues incubator, the northern equivalent was John Mayall's Blues Breakers from Manchester. Like Blues Incorporated, the Blues Breakers was a fluid organisation, which attracted a string of important musicians. Eric Clapton joined in 1965 and was a key figure in their influential album, Blues Breakers and Eric Clapton. The debt to American bluesmen was clear - 'Ramblin' On My Mind'17 (Robert Johnson), 'Steppin' Out' (Memphis Slim) and 'It Ain't Alright' (Little Walter) - but there were four of Mayall's compositions and a joint effort with Clapton ('Double Crossing Time'.) Clapton left almost immediately to form Cream, with Ginger Baker and Jack Bruce. His replacement, Peter Green, a gifted instrumentalist and singer/songwriter, became better known as a member of Fleetwood Mac.

Another influential early group was Geno Washington and the Ram Jam Band, which started playing in the early 1960s when Washington was stationed at RAF Bentwaters, Suffolk. Their repertoire was eclectic, including 'Que Sera Sera', but mixed rhythm and blues and soul. ${ }^{18}$ There were similarities between its music and the Rolling Stones, who were by far the most successful English band to emerge from the early '60s boom. Skiffle provided the entree to the blues for several members, Blues Incorporated offered a first opportunity to perform in public and in Brian Jones they had a wealth of 
information and records from which to develop their act. After a debut performance at the Marquee, they gained a residency at the Crawdaddy before going on their first tour. The line-up stabilised in 1963, after Bill Wyman and Charlie Watts joined, and they released their first record before undertaking a bigger national tour in the same year. In the early days they were, selfconfessedly, imitative, with Chuck Berry ('Come On,' Bye Bye Johnny' and 'Carol'), Willie Dixon ('Route 66' and 'I Just Want to Make Love to You') and Muddy Waters ('I've Got My Mojo Working' and 'I Can't Be Satisfied') particular favourites, though this did not stop them drawing on other sources, (Lennon/McCartney 'Wanna Be Your Man' and Holly/Petty 'Not Fade Away,' for example) and including a few of their own compositions. ${ }^{19}$

Initial responses to British rhythm and blues bands in general were often negative, encapsulated in Sonny Boy Williams claim that 'they wanted to play blues so badly ... and they did.' Allegations about 'white imposters' were part of an essentialist claim that only 'Negroes' could sing the blues. ${ }^{20}$ As one critic in Jazzbeat bewailed, 'groups such as the Rolling Stones are taken seriously and ... several thousand teen-age fans ... believe they have heard some authentic rhythm and blues. ${ }^{21}$ Later judgements still referred to the "whitened versions of African American rhythm-and-blues' offered by the Stones. ${ }^{22}$ Precisely what is meant by 'whitening' remains unclear, but to move to a non-judgemental and dynamic view, the Stones can be seen as moving from imitation, through experimentation to the creation of a distinctive approach that made sense to them and their audience. ${ }^{23}$ This was clear in their distinctive rendition of 'The Last Time' and especially 'Not Fade Away', in which Buddy Holly met Bo Diddley in London. ${ }^{24}$ Equally important were the experiments in song writing. While never matching Lennon/McCartney, the Jagger/Richards duo produce some important and successful songs, particularly 'I Can't Get No Satisfaction,' which was covered by both Otis Redding and Aretha Franklin. ${ }^{25}$ Even more striking was the success that the Stones had in America, where interest in blues music had been in decline for several years. As part of the 'British Invasion,' British rhythm and blues bands rekindled an appreciation of a music and musicians who had sunk into obscurity. Muddy 
Waters claimed that 'before them people [in America] didn't know anything about me ... Then the Rolling Stones and all those other English bands came along, playing this music, and now the kids are buying my records and listening to them. ${ }^{26}$ Although the Stones were to experiment (with mixed success) with other musical forms, they never totally abandoned their rhythm and blues roots and in 2016 produced a cover album, Lonesome \& Blue, that featured songs by well-known figures, such as Little Walter, Willie Dixon and Howlin' Wolf, and lesser-known performers like Magic Sam and Eddie Taylor.

The Stones were not alone. The Yardbirds, who took over the residency at the Crawdaddy Club, drew heavily on Chicago blues singers, such as Howlin' Wolf and Muddy Waters. Sonny Boy Williamson and the Yardbirds, the album of the tour, was recorded in December 1963 at the Crawdaddy Club. Five Live Yardbirds was a cover album of well-known blues numbers, but the instrumental breaks allowed guitarist, Eric Clapton to show off his ability, particularly in duets with Keith Relf (harmonica) on 'Smokestack Lightening' and with Paul Samwell-Smith (bass guitar) on 'Here 'Tis.' ${ }^{27}$ The Animals, with a distinctive singer in Eric Burdon and an equally outstanding keyboard player in Alan Price, produced a string of blues-inspired singles - 'Boom, Boom,' 'See See Rider' and especially 'House of the Rising Sun' - as well as a more upbeat version of Nina Simone's 'Don't Let Me Be Misunderstood' and Sam Cooke's 'Bring It On Home. ${ }^{28}$ Among other groups, Them, with another distinctive singer in Van Morrison, the Spencer Davis Group and the Moody Blues covered a range of blues standards, ('Dimples,'Bright Lights, Big City' and 'Route 66') with Motown songs and their own bluesinfluenced compositions. Similarly, the Small Faces, in their early work, were influenced by rhythm and blues. The success of groups such as this bear witness to the extent to which more mainstream pop music was being infiltrated, but this transition also created internal tensions. This was clearly seen in the career of Manfred Mann.The group had its origins in the Mann-Hugg Blues Band, which had backed Sonny Boy Williamson, with mixed success. Teaming up with Paul Jones, a good friend of Brian Jones of the Rolling Stones, as lead vocalist, they become Manfred Mann. Their first album, The Five Faces of Manfred Mann, contained blues numbers, such as 'Hoochie Coochie 
Man' and 'I've Got My Mojo Working,' but their singles, ('5-43-2-1,'Do Wah Diddy Diddy' and 'Sha La La') were increasingly pop-oriented, which created tensions with Jones and bass-player Jack Bruce. Both left - Bruce to become a member of Cream, Jones to set up his own Blues Band. ${ }^{29}$

The height of the rhythm and blues boom was largely over by the late 1960s, though Fleetwood Mac, with the distinctive presence of Peter Green, proved to be almost as long-lived as the Stones. However, later groups, such as the Jam and Style Council, with Paul Weller as the common factor, even Squeeze acknowledge their (partial) debt to rhythm and blues. Jules Holland later formed his highly successful and influential Rhythm and Blues Orchestra in the 1980s, while Bill Wyman's Rhythm Kings have been touring since the early 1990s. More generally, elements of rhythm and blues migrated into much mainstream pop music, and, notwithstanding the fears of bastardization and the cries of dilution, popular music since the 1960s, has been profoundly influenced by it in its numerous commercial variants.

\section{Soul Music-America hits back}

One of the most interesting and important musical figures in Britain was Clive Powell, better known as Georgie Fame. ${ }^{30}$ His route to prominence was in many respects unsurprising. Inspired by skiffle and early rock 'n' roll - from coffee bar juke boxes to Elvis on screen in 'Jailhouse Rock' and Buddy Holly live at the Ritz, Wigan - he played boogie-woogie piano in a local dance band, did a season at Butlins, before moving to London, gigging in various Soho pubs and clubs. His first breakthrough came with the Marty Wilde Big Beat Show, as backing pianist for the likes of Billy Fury and Dickie Pride. More importantly, during the 1960 Eddie Cochrane/Gene Vincent tour, he discovered the music of Ray Charles and switched to the Hammond organ. His second breakthrough came with a residency at the Flamingo Club in 1962, which was to last until 1965. There, and while on tour at various American military bases, such as Chicksands and Alconbury, and at northern clubs, such as the TwistedWheel in Manchester, he encountered a range of musical influences. His first album, with the Blue Flames, $R \& B$ At the Flamingo, lived up to its title 
with tracks such as 'Baby Please Don't Go,' 'Parchman Farm' and 'Night Train' but also included Smokey Robinson's 'Shop Around.' By 1966 and the third album, Sweet Things. the soul influence was clear in versions of Sam Cooke's 'The Whole World's Shaking' and Rufus Thomas's 'The World Is Round. ${ }^{31}$ Even more strikingly, he was the only white artist on the 1965 Tamla Motown tour, headed by the Supremes and including Smokey Robinson and the Miracles, Martha and the Vandellas, the Earl Van Dyke Six and an almost unknown fifteen-year old by the name of Stevie Wonder. In fact, the tour was less than successful outside London venues but the mid-1960s still witnessed the growing popularity of soul music.

Soul music in America had emerged from an amalgam of gospel and rhythm and blues. Its roots went back to the days of slavery and the post-Civil War success of the Fisk Jubilee Singers, who toured Europe, visiting London in 1873, and regaling Victoria with songs such as 'Steal Away to Jesus' and 'Go Down Moses.' ${ }^{32}$ It was a tradition that remained strong in the twentieth century. Groups such as 'The Blind Boys of Mississippi,' 'The Blind Boys of Alabama' and especially the Staple Singers were all prominent in black communities during the quarter century after the second world war. The crossover to secular and more mainstream, white music (and from this the crossover from America to Britain) was complex and problematic. Groups like the Drifters, originally a doo wop group with Clyde McPhatter as the lead singer, or solo singers such as Lavern Baker and Ruth Brown made some impact but the most important figure from the 1950s was Ray Charles, who combined jazz and blues but also country and western music. ${ }^{33}$ It was, however, the Berry/Gordy Tamla Motown 'production line,' with its intention of giving a sense of black identity to ghetto kids, as well as making money, that churned out a stream of chart successes between 1964 and 1967 and made household names of the Supremes, Martha and the Vandellas, and Smokey Robinson and the Miracles. ${ }^{34}$ Other key figures included Sam Cooke, whose musical career, aroused much criticism at times, despite his 'double-voiced' performances of what has been termed 'ethnically marked music. ${ }^{35}$ Problematic in a different way was the explicit support given to the civil rights movement by Nina Simone 
('Mississippi Goddam') and Aretha Franklin (notably the chart success, 'Respect') and the assertion of black pride by James Brown (especially 'Say It Loud'). ${ }^{36}$ Although racial tensions were less apparent in Britain, it was difficult to divorce such singers and their music from wider racial politics.

Soul singers were not confined to American performers. Dusty Springfield, who started her career as a member of a folk-pop group, was a major figure in the popularisation of Motown. Several groups moved from rhythm and blues to soul - Georgie Fame and the Blue Flames, the Spencer Davis Group and the Small Faces - while the Jamaican duo, Bob and Marcia, took one of Nina Simone's better known songs, 'Young, Gifted and Black,' into the charts for ten weeks in spring 1970. ${ }^{37}$ Further, imported soul records, the more obscure the better, were at the heart of the dance-oriented Northern Soul scene which encompassed not only wellknown venues, such as Wigan Casino, The Twisted Wheel and Blackpool Mecca, but also The Shades in Northampton and The North Park Club in Kettering. ${ }^{38}$

\section{The appeal of rhythm and blues and soul}

The popularity of rhythm and blues and soul is clear but raises some interesting questions. Put simply: why should the music of troubled slaves on plantations in the southern states of ante-bellum America appeal to the relatively well-to-do youths of suburban Britain? How could the Mississippi Delta be relocated on the Thames, let alone the Tyne? That there was an appeal cannot be doubted. Ray Davies, Eric Clapton and John Steel, of the Animals, gave voice to a wider felt sense of identification. ${ }^{39}$ Part of the attraction may have been found in that combination of fear and fascination that had helped blackface minstrelsy maintain its popularity. In that respect, the ante-bellum southern plantation construction offered a semi-sanitised and safe depiction. There was suffering in the songs, but it was less problematic and threatening for being in a different time and place. The argument should not be overstated $^{40}$. In early-1960s Britain, there was an awareness of racial injustice and its victims, however idealistic and naive in hindsight. The plight of Civil Rights marchers was to be seen on British television. Martin Luther King's campaign, notably 
his 'I Have A Dream' speech received wide media coverage as did his assassination. Similarly, Aretha Franklin and James Brown were high-profile figures, whose music was part of, not simply a backcloth to, the civil rights movement. Additionally, the scurrilous arguments, particularly in Smethwick, during the 1964 general election gave further immediacy to the issue of racism in England. It is easy to be dismissive of the white, suburban make up of rhythm and blues club members, but the post-war generation had grown up in a society that was more ethnically mixed than ever before. Paul Oliver, the highlyregarded writer on the blues, looking back on the 1960s from the vantage point of the 1990s, noted that 'the music of a segregated minority was a symbol of the gulf between themselves and the values and attitudes of their parents. ${ }^{41}$

The music provided one means of coming to terms with ethnically-mixed, post-imperial Britain, at a time when many members of older generations appeared (and indeed were) wedded to outmoded ideas of the Empire and its inferior races. Post-war changes, the accelerating loss of Empire, the humiliation of Suez, the Notting Hill riots and the growing number of New Commonwealth migrants gave rise to debates about the meaning of Englishness. ${ }^{42}$ The comfortable sense of national identity and cohesion that grew out of the (often mythologised) experiences of the second world war was visibly crumbling in the 1950s and early 1960s. A range of commentators, often sympathetic to improving 'race relations', still shared a 'Them and Us' view of society, in which there were 'white' hosts and 'black' visitors, and in which the latter were expected to conform to the values and codes of behaviour of the former. Thanks in no small part to the 'People's War,' the white working-classes were no longer a 'race apart' and had been incorporated into the national community. The new 'race apart' were those immigrants from the Caribbean and south Asia who were clearly identified by the colour of their skins. ${ }^{43}$ For many in the wartime and pre-war generations, for whom society had been overwhelmingly white, such formulations may have made sense, but for some of the postwar generations, growing up in a society that was becoming year-on-year more ethnically diverse, they did not. Over time shared musical interests helped foster a wider awareness of and 
sympathy for 'others' in society. Northern 'Soulies', irrespective of ethnicity, looking back from the 1990s, stressed friendliness and the way in which the scene provided a safe environment. ${ }^{44}$ However, hindsight can sanitise the past. Welcoming new musical cultures did not necessarily bring acceptance of a new, more diverse society. Eric Clapton's oft-quoted drunken rant, in which he voiced his support for Enoch Powell, demonstrates that it was perfectly possible to like 'black' music but not like the presence of 'black' people in the country. ${ }^{45}$

There were also more immediate reasons for the popularity of rhythm and blues and soul that related to the novelty of the music and the experience of clubs and concerts. In an age when pop music seemed dominated by safe but homogenised music, from the post rock 'n' roll Cliff Richard to Adam Faith, not to mention Bobby Vee, there was something raw, and therefore seemingly authentic, about the sound of John Mayall and Cyril Davies or Ray Charles and Aretha Franklin. There was something exciting about the guitar driven rhythm and blues of the Yardbirds and a depth of feeling to the singing of Georgie Fame. There was something spontaneous about the performance of Mick Jagger or James Brown. Paul Oliver's conclusion that rhythm and blues was music to dance to was fundamentally correct. ${ }^{46}$ In fact, part of the attraction, contrary to the belief that blues was simply about suffering, was that the music and the lyrics, blues and soul alike, encompassed a range of emotions, including not least unashamed pleasure.

\section{Some concluding observations}

The growing interest in the blues and the subsequent rhythm and blues boom, and soul, more so than the advent of ragtime and jazz, had a major impact on popular music in this country. Arguments about 'authenticity, interesting for the light they throw on contemporary attitudes, obscure the fact that the mid-1960s in particular saw, a period of initial imitation, experimentation and development of a distinctive British approach that embraced rhythm and blues and soul. These developments were part of a wider and complex African musical diaspora that links parts of Africa, Europe and America, and the Caribbean. London particularly, but also Liverpool, Birmingham and Manchester, were important 
meeting places for differing musical traditions in which the complex reworking of other music by the dominant culture created 'a circuit of production and exchange. ${ }^{47}$ Further, from a more individual perspective, this experimentation and evolution was part of longer career trajectory, not necessarily involving a return to blues roots, and embracing other musical genres, notably soul but also ska, from which was created a multi-faceted 'alternative authenticity', rather than imitation of other cultures, which defied simple categorisation. ${ }^{48}$ More broadly, the involvement with different musical cultures from African, African-American and African Caribbean sources was part of a process of adjustment whereby all generations had to confront questions of identity, and to which we now turn.

\section{Endnotes}

1 Mezz Mezzrow, 'Blues are the pattern for authentic jazz,' Melody Maker, 27 March 1948, p.2 cited in R F Schwartz, How Britain Got the Blues:The Transmission and Reception of American Blues Style in the United Kingdom, Abingdon, Routledge, 2016, p.21

2 Billy Bragg notes that 'Rock Island Line' was not written by Lead Belly, the line itself didn't go to New Orleans and there were no toll gates but, other than that, there was nothing wrong. B Bragg, Roots, Radicals and Rockers: How Skiffle Changed the World, London, Faber \&Faber, 2017, p.3

3 Technically their importation remained illegal until 1960.

4 Production was limited to 99 copies to avoid the imposition of Purchase Tax, at 33.3 per cent on imprints of 100 or more.

$5 \quad \mathrm{AFN}$ and Radio Luxembourg played more blues music, but the extent should not be overstated.

6 Dupree was an important popularizer, especially in the north of England, where he lived (Halifax) and played in local pubs and clubs for about a decade from the mid-1960s to the mid-1970s.

7 Cited in Schwartz, How Britain Got the Blues, p.150.The band in question was the Yardbirds.

8 The tours continued in Europe until 1985. The British venues included predictable places - London Hammersmith, Manchester Free Trade Hall and, with no sense of irony, the Colston Hall, Bristol. In addition to the major English cities (Bradford, Newcastle, Leicester, Birmingham, and Sheffield) performances were also held in Bournemouth, Boston, Darlington, Hemel Hempstead and Sunderland.

9 Victoria Spivey, aka Queen Victoria, was a talented multi-instrumentalist, singer and dancer whose recording career lasted from the mid-1920s to the 
early 1960s. Among her accompanists on record were Louis Armstrong, Lonnie Johnson and (in 1962) Bob Dylan. For her performance on I Hear the Blues see https://www.youtube.com/watch?v $=$ Gnqi5b5CAvw

10 From his first tour in 1951 Big Bill Broonzy was more than happy to play up to an 'authentic' image, being billed as 'one of the great Mississippi Delta Men,' even though, as several commentators have noted, his playing style had more in common with Texas bluesmen, such as Blind Lemon Jefferson. Authenticity claims could create problems. An attempt to produce an album of Lead Belly songs by John Lee Hooker collapsed when it transpired that he did not know any Lead Belly songs! For the construction of Lead Belly as the paradigmatic bluesman, see R Cole, 'Mastery and Masquerade in the Transatlantic Blues Revival,' Journal of the Royal Musical Association, 143(1), 2018, pp.173-210, at p.180. More generally, Cole stresses how the blues revival 'forced African American artists into assuming the mask of black face minstrelsy,' at p.174

11 The same could be said of the construction of Jimi Hendrix's image with its highly sexualised and wild traits.

12 Cole, 'Mastery and Masquerade' especially pp.184-7

13 Review of John Lee Hooker 'Hoogie Boogie' b/w 'Whistlin' and Moanin' Blues' in Melody Maker 24 May 1952 cited in Schwartz, How Britain Got the Blues, p.56

14 Albert McCarthy was a well informed and well-regarded jazz and blues critic who edited several specialist publications in the 1940s and 1950s.

15 The 1964 festival saw Memphis Slim, Jimmy Witherspoon and Mose Allison perform alongside (among others) the Rolling Stones, Manfred Mann, the Yardbirds (including Eric Clapton), Georgie Fame and the Blue Flames and the Graham Bond Organisation.

16 https://www.youtube.com/watch?v=STjn0ZM5JiI

17 https://www.youtube.com/watch? $\mathrm{v}=\mathrm{qEhjcqzdoxU}$

18 'J Stratton, 'Melting Point: The Making of British Black Music in the 1950s and 1960s' pp.27 -45 at p.36 in J Stratton and N Zuberi, eds., Black Popular Music in Britain Since 1945, Abingdon, Routledge, 2014

19 For 'Come On' see https://www.youtube.com/watch?v=-OLkVbDA3OQ and 'I Just Want to Make Love to You' https://www.youtube.com/ watch? $=$ UV7aIJs4NFk

20 The singing of Long John Baldry and Eric Burdon showed that at least some white men could sing the blues.

21 Cited in Schwartz, How Britain Got the Blues, p.142. Interestingly in an interview with Melody Maker (2 May 1964) Jagger was quite explicit: '... don't listen to us. Listen to the men [sic] who inspire us.' And asked: 'Why get your information second-hand when it's fairly easy to buy it new?' Similarly, Keith Richards described the early Stones as 'a white London imitation of South Side Chicago blues.' Cited in D Allen, 'Feelin' bad this morning: why the British blues? Popular Music, 26(1), 2007, pp.141-156 at p.143.

22 J Stratton, 'Popular Music, Race and Identity', The Sage Handbook of Popular Music, London, Sage, 2015, pp.381-400 at p.395. Stratton specifically refers to a version of 'Poison Ivy' by the Australian band, Billy Thorpe and the 
Aztecs who 'whitened the Rolling Stone's whitened version of the original.' Thorpe's version is clearly pop but the difference between the Stones and the Coasters is less obvious. For Thorpe's version see https://www.youtube. $\mathrm{com} /$ watch? $\mathrm{v}=\mathrm{WrHoEx} 7 \mathrm{cpDM}$, the Stones at https://www.youtube.com/ watch? $\mathrm{v}=\mathrm{h} 9 \mathrm{rTWP}$ sJh6o\&list $=\mathrm{RDh}$ PrTWPsJh6o\&start_radio $=1 \& \mathrm{t}=8$ and the Coasters at https://www.youtube.com/watch?v=ZRfRITVdz4k

23 Interesting J Stratton elsewhere makes the point that the Stones were 'trying to make sense of the music and utilise it for a different cultural purpose.' Stratton, 'Melting Point' pp.27 -45 at p.35.

24 For the original version by the Crickets see https://www.youtube.com/ watch? $\mathrm{v}=\mathrm{NN} 2 \mathrm{~L} 84 \mathrm{dvoag}$, and the Stones at https://www.youtube.com/ watch? $=$ gIKfN3CuFXA. The debt to Bo Diddley can be seen via https:// www.youtube.com/watch?v=7XsSQG6GDrQ

25 The Stones at https://www.youtube.com/results?search_ query $=\mathrm{i}+$ can $\% 27 \mathrm{t}+$ get + no + satisfaction + the + rolling + stones, Otis Redding at https://www.youtube.com/watch? $\mathrm{v}=\mathrm{CpmZWUPrCgo}$ and Aretha Franklin at https://www.youtube.com/watch?v=3r4rsp_1NQ0

26 Cited in Allen, 'Feelin' bad this morning,' p.143

27 For 'Smokestack Lightning' see https://www.youtube.com/ watch?v=1IHrXlxoWKU and 'Here 'Tis' https://www.youtube.com/ watch? $\mathrm{v}=\mathrm{AdBWokA} 8 \mathrm{Hjc}$

28 For 'House of the Rising Sun' https://www.youtube.com/ watch? $v=0$ Fy7opKu46c, 'Don't Let Me Be Misunderstood' https://www. youtube.com/watch?v=Bw7RTUEZMyg and 'Bring It On Home' https:// www.youtube.com/watch?v=8EoS7GDSu0U

29 For 'Hoochie Coochie Man' see https://www.youtube.com/ watch?v=SYK2vO_S1XA. Compare with 'Do Wah Diddy Diddy' https:// www.youtube.com/watch? $v=43 \mathrm{vOAw} 2 \mathrm{sAFU}$ and 'Sha La La' https://www. youtube.com $/$ watch? $=\mathrm{Xz} 2 \mathrm{CXDFmz} 5 \mathrm{w}$

30 The following paragraph draws heavily on K Gildert, Images of England Through Popular Music: Class, Youth and Rock ' $n$ ' Roll, 1955-1976, Basingstoke, Palgrave, 2013, chapters 2 and 3.

31 Baby Please Don't Go https://www.youtube.com/watch?v=TiAN8rAqYgg and The Whole World's Shaking https://www.youtube.com/ watch? $\mathrm{v}=5 \mathrm{vG0sISL} 9 \mathrm{QY}$

32 Fisk College was established in Nashville after the Civil War by the American Missionary Association and its touring choir was a crucial source of funds. Even before this, interest in gospel music had seen the publication of 'Slave Songs of the United States' in 1867, which included 'Roll Jordan Roll,' Jacob's Ladder' and 'Deep River.'

33 In particular, the two-volumed Modern Sounds in Country \& Western Music, 1962 had a major impact on both sides of the Atlantic, as a black man sang the white music of Hank Williams (for example, 'Take These Chains From My Heart' and 'Your Cheatin' Heart') and Don Gibson, ('I Can't Stop Loving You') to a lush orchestral sound and backing singers.

34 For example, Supremes 'Baby Love' https://www.youtube.com/watch?v=9_ y6nFjoVp4 Martha and the Vandellas 'Dancing in the Streets' https:// 
www.youtube.com/watch? $\mathrm{v}=\mathrm{CdvITn} 5 \mathrm{cAV}$ c Other groups include the Marvelettes, who had the first Motown number 1.

35 M Burford, 'Sam Cooke as Pop Album Artist - A Reinvention in Three Albums,'Journal of the American Musicology Society, 65(1), 2012, pp.113-78

36 Mississippi Goddam https://www.youtube.com/watch?v=LJ25-U3jNWM Respect https://www.youtube.com/watch?v=6FOUqQt3Kg0 Say It Loud https://www.youtube.com/watch?v=9bJA6W9CqvE

37 At https://www.youtube.com/watch? $\mathrm{v}=\mathrm{ubDVUQ}$-n5BE

38 See D Nowell, The Story of Northern Soul, London, Portico, 2015

39 M Doyle, The Kinks: Songs of the Semi-Detached, Reaktion Books, London, 2020, pp. 32, 51-2

40 Cole, for example, talks of 'vicarious identity politics' among white fans. for whom 'a primitive racialized alterity [was] a perfect antidote to the flourishing mass consumerism of the so-called affluent society,' Mastery and Masquerade,' p.196.

41 P. Oliver Story of the Blues, London, Pimlico, 1997, p.193 cited in Allan, 'Feelin' bad this morning,' p.144,

42 Britishness and Englishness were often used interchangeably - by the English. Even in the 1950s, there was a growing awareness of distinctive Scottish, Welsh and Irish identities, though the latter was considerably complicated by the existence of a border on the island of Ireland and a community in the north that often seemed more British than the British.

43 C Waters, "Dark Strangers" in Our Midst: Discourses of Race and Nation in Britain, 1947-1963,' Journal of British Studies, 36(20, 1997, pp.207-38

44 L Back, 'Voices of Hate, Sounds of Hybridity: Black Music and the Complexities of Racism,' Black Music Research Journal, 20(2), 2000, pp.127-49

45 See also Back, 'Voices of Hate' and the discussion of skinhead reggae.

46 Oliver, Story of the Blues, p.193

47 Stratton, 'Melting Point,' especially p.28. Stratton draws heavily on P Gilroy, The black Atlantic: modernity and double consciousness, London, Verso, 1993

48 Allen, 'Feelin' bad this morning,' p.154 